\title{
Desain Konfigurasi Ruang Permukiman Cikoang Berbasis Desa Wisata
}

\author{
Hartawan $^{1 *}$, Victor.S ${ }^{1}$, Triyatni.M ${ }^{1}$, Rahmi Amin ${ }^{1}$, Nurul Najdmi ${ }^{1}$, Edward Syarif ${ }^{1}$, Abdul \\ Mufti $^{1}$, Andi Karina ${ }^{1}, \mathrm{D}$, Muh Yogi.R ${ }^{1}$ \\ Departemen Arsitektur, Fakultas Teknik Universitas Hasanuddin ${ }^{1}$ \\ hartawan@unhas.ac.id*
}

\begin{abstract}
Abstrak
Pariwisata adalah sektor yang masih menjadi andalan penggerak pengembangan suatu kawasan. Kegiatan pariwisata ini akan menjadi primadona penggerak peningkatan ekonomi khususnya bagi kawasan yang memiliki potensi unik dan sumber daya langka. Kriteria kepemilikan potensi keunikan dan kelangkaan dapat ditemukan di Desa Cikoang Kecamatan Mangarabombang Kabupaten Takalar. Perpaduan suasana muara sungai dengan keasrian lingkungan dalam balutan temperatur udara yang nyaman didukung oleh ritual tahunan Maudu Lompoa dan hasil tangkapan ikan segar nelayan adalah potensi wisata yang sulit dilupakan bagi pelancong yang bercita rasa tinggi. Kondisi seperti ini tentunya patut untuk dibagi kepada seluruh masyarakat pencinta wisata dunia. Potensi tersebut sangat disayangkan karena lingkungannya telah menunjukkan adanya gejala penurunan kualitas lingkungan dan kurangnya fasilitas pendukung untuk membantu menampakkan keunggulannya. Penurunan kualitas lingkungan dan kekurangan fasilitas penunjang adalah permasalahan pengabdian ini. Sedangkan upaya untuk memunculkan potensi emas wisata desa muara tepi sungai adalah tujuan pengabdian. Metode yang digunakan untuk menyelesaikan masalah adalah pendekatan deskripsi arsitektural dengan pertimbangan kesatuan antara unsur budaya, wisata, pendidikan dan kuliner. Hasil kajian melahirkan gagasan tata ruang kawasan yang terintegrasi antara kegiatan budaya, pendidikan dan rekreasi. Penyelesaian kawasan tepi air muara sungai dengan konstruksi penahan erosi sebagai tempat wisata adalah solusi bernilai tambah gabungan. Peningkatan kawasan wisata tambak penggaraman sebagai gabungan wisata dan pendidikan. Peningkatan kawasan wisata budaya maudu lompoa sebagai gabungan wisata budaya. Penataan rancangan desa Cikoang berbasis wisata menghasilkan tatanan ruang dan rancangan arsitektural yang menggabungkan wisata budaya, pendidikan, kuliner, dan pemandangan muara sungai sebagai satu kesatuan yang terintegrasi akan mengantarkan Desa Cikoang menjadi kawasan wisata desa yang berkualitas tinggi.
\end{abstract}

Kata Kunci: Desa Wisata; Turap Erosi; Tepi Muara Sungai; Pencinta Wisata Dunia; Ritual Tahunan.

\begin{abstract}
Tourism is the main sector to generate the development. This tourism activity will be the lead of driving the regional to improve the economic sector in some area, especially for the areas that have unique potential and scarce resources. The criteria for ownership of potential uniqueness and rarity can be found in Cikoang Village, Mangarabombang District, Takalar Regency. The combination of the atmosphere of the river estuary with the natural beauty of the environment wrapped in a comfortable air temperature supported by the annual ritual of Maudu Lompoa and the catch of fresh fish from fishermen is a tourism potential that is hard to forget for travelers with high taste. Conditions like this certainly deserve to be shared with all people who love tourism. This potential is unfortunate because the environment has shown signs of deteriorating environmental quality and lack of supporting facilities to help show its superiority. The decline in environmental quality and lack of supporting facilities are the problems of this dedication. Meanwhile, efforts to bring out the golden potential of riverbank estuary village tourism are the goal of dedication. The method used to solve the problem is an architectural description approach with the consideration of the unity between elements of culture, tourism, education and culinary. The results of the study promote architectural idea of an integrated regional spatial plan between cultural, educational and recreational activities. Completion of the watershed area of the estuary with erosion protection construction as a tourist spot is a combine value added solution. Increasing the salt pond tourism area as a combination of tourism and education. Increasing the Maudu Lompoa cultural tourism area as a combination of cultural tourism. The arrangement of the Cikoang village design based on tourism produces a spatial layout and architectural design that combines cultural tourism, education, culinary, and views of the river estuary as an integrated unit that will lead Cikoang Village to become a high-quality village tourism area.
\end{abstract}

Keywords: Tourism Village; Erosion Retaining Wall; River Estuary; Tourism; The Annual Ritual. 


\section{Pendahuluan}

Desa Cikoang Kecamatan Mangarabombang Kabupaten Takalar adalah desa yang telah memiliki nama yang melekat dalam histori masyarakat etnis Makassar di Provinsi Sulawesi Selatan. Tempat ini terletak di sebelah selatan Kota Makassar dengan jarak tempuh normal sekitar satu setengah jam perjalanan darat. Akses dapat dipilih melalui tiga alternatif jalur yaitu jalur pantai, jalur tengah, dan jalur lingkar luar Gowa. Jalur pantai terletak di sebelah barat mengikuti garis pantai barat semenanjung Sulawesi Selatan dengan jarak 58,1 Km memerlukan waktu tempuh 1 jam dan 42 menit. Jalur tengah membelah kota Sungguminasa dan Kota Takalar berjarak 53.9 Km memerlukan waktu 1 jam 26 menit. Jalur lingkar luar Gowa melintasi Jenne Tallasa berjarak $57.5 \mathrm{Km}$ dan memerlukan waktu 1 jam dan 43 menit.

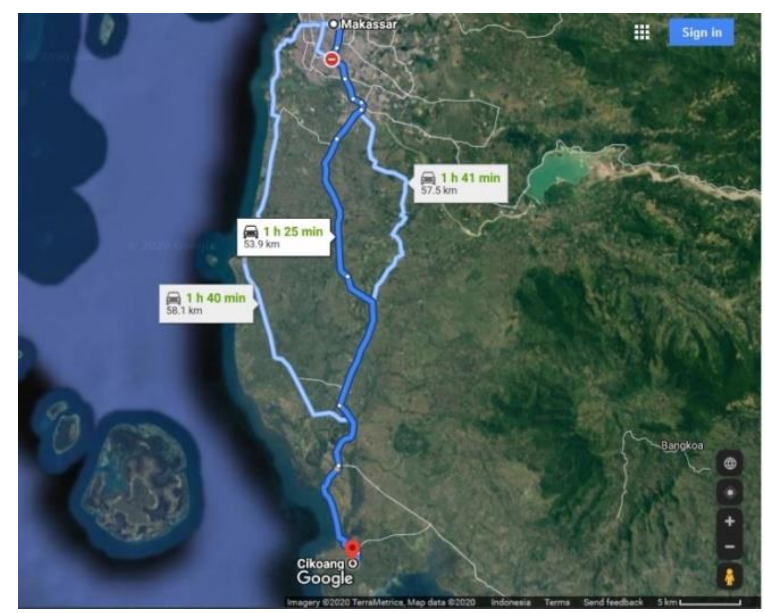

Gambar 1. Peta lokasi kawasan pengabdian

Kawasan ini memiliki nama tersendiri di kalangan masyarakat Sulawesi Selatan dan bahkan Indonesia akan adanya tradisi rutin relegi tahunan yang disebut Maudu Lompoa. Cikoang secara sejarah lebih kenal sebagai tempat berlabuhnya pembawa ajaran Islam oleh keturunan Nabi Muhammad SAW yang ke 27, bernama Sayyid Jalaluddin. Desa Cikoang berada di muara sungai Cikoang, Lingkungan desa ini menyimpan sejuta potensi yang tidak dapat dijelaskan dalam narasi secara lengkap untuk menerangkan kondisi riilnya. Suasana alamiah yang kental dengan suhu udara yang sejuk menjadikan Kawasan ini bagai surga dunia. Potensi besar ini ternyata belum di manfaatkan secara optimal atau kemungkinan belum dilirik oleh mata usahawan.

Desa Cikoang yang berada di mulut muara sungai menampilkan pemandangan alam yang luar biasa keindahannya. Sungai yang dihiasi riak gelombang menambah suasana sejuk rasa dan pemandangan. Suhu udara sejuk disertai hembusan angin semilir membuat kualitas rasa sempurna dambaan perindu kenikmatan alamiah yang berkualitas tinggi.

Masyarakat desa melewati hari-harinya dengan penuh senyum dan bahagia. Hasil tangkapan nelayan dapat diperoleh dengan mudah dari tepi sungai. Pengisi waktu lowong dapat dilakukan dengan memancing di sungai yang berair bening mengandung ikan segar. Lalu lintas perdagangan hasil tangkapan nelayan sebagai roda ekonomi dan distribusi hasil tambak garam menjadi ciri khas daerah ini. 


\section{Latar Belakang Teori}

Wisata adalah bidang yang menjadi alternatif untuk pengembangan dan peningkatan suatu kawasan. Kegiatan ini dapat menjadi motor penggerak bidang bidang terkait dan akan menjadi pendorong pergerakan dan peningkatan ekonomi. Kegiatan penunjang wisata seperti usaha kuliner, penginapan, pengiriman barang, jasa transportasi, jasa guide, penjualan tiket dan sebagainya akan menjadi rantai kegiatan yang saling berhubungan. Efek samping dalam hal pengembangan wawasan masyarakat tempat wisata terselenggara akan menerima imbas pembukaan wawasan yang lebih luas dan menglobal.

Pentingnya kegiatan ini menjadikan para peneliti menjadi terlibat dalam hal upaya pengembangan dan pembukaan kawasan baru. Penelitian tentang efek wisata terhadap lingkungan dan persepsi masyarakat hingga ketersediaan energi untuk kelengkapan kebutuhan telah terungkap untuk mendukung kelancaran dan kelangsungan kegiatan wisata.

Kegiatan wisata yang umum dikenal adalah wisata yang menawarkan unsur modern. Kegiatan ini umumnya menjamur di pusat kota yang ramai. Pada sisi lain terdapat wisata yang berkembang di alam terbuka dalam bentuk wisata alam dengan keindahan dan keunikan spesifik yang dimilikinya.

Indonesia sebagai negara Kepulauan memiliki potensi besar untuk dikembangkan menjadi kawasan wisata baru selain kawasan wisata yang telah unggul dan dikenal selama ini. Potensi lain yang memiliki peluang besar untuk dikembangkan adalah kegiatan wisata desa. Kegiatan wisata ini ternyata menjanjikan peluang pengembangan dan citra tersendiri.

Kegiatan wisata adalah salah satu bentuk usaha yang menjanjikan peningkatan ekonomi masyarakat di suatu kawasan. Kegiatan ini melibatkan berbagai pihak yang terkait untuk menjamin kelancaran dan pengembangannya. Masyarakat sebagai bagian yang tak terpisahkan adalah kunci utama upaya kelangsungan wisata. Dengan demikian persepsi masyarakat sekitar kawasan wisata terhadap kagiatan ini perlu diperhatikan dan diamati secara tepat. Di Desa Baksi Baiburt Turki terungkap bahwa pelibatan masyarakat setempat untuk pengembangan wisata di desanya adalah sangat penting. Termasuk potensinya sebagai sumber informasi yang menguasai medan dan dalam hal pemberian rekomendasi (Olcer, C. and Ekiz, E. H. 2016).

Kegiatan wisata dalam satu kawasan tidak hanya menjanjikan keuntungan dan pengembangan yang bersifat positif. Hal sebaliknya dapat terjadi sebagai efek domino dari suatu kegiatan yang perlu diperhatikan dan dipertimbangkan secara adil dan bijaksana. Kehadiran wisata disuatu kawasan dapat memicu terjadinya loncatan pengembangan di kawasannya dan dapat menimbulkan kecemburuan sosial dan bahkan konflik antar daerah, terutama bagi kawasan sekitarnya yang tidak mendapatkan imbas positif dari kawasan wisata yang ada. Hal ini terjadi di desa Moieciu de Sus, Moieciu Resort, Romania (Matei, D. 2018).

Kegiatan wisata disuatu kawasan dapat menciptakan lapangan kerja baru. Usaha perjalanan, penjualan tiket, pengiriman barang, akomodasi dan lainnya menjadi ikutan pengembangan kegiatan wisata. Akibatnya peningkatan ekonomi masyarakat akan menjadi efek yang diharapkan. Suatu kawasan yang telah berkembang dalam hal pariwisata tidak berarti bahwa mereka akan menikmatinya secara otomatis sepanjang masa. Hal yang perlu diperhatikan tentunya adalah keberlanjutan wisata disuatu kawasan. Untuk mempertahankan kelanjutan kegiatan wisata perlu dilakukan berbagai upaya, diantaranya melakukan pengukuran terhadap 
kepuasan para pengunjung. Kepuasan pengunjung secara sederhana dapat dipastikan menjadi target dan harapan pengunjung di setiap kegiatan bisnis termasuk bisnis wisata. Kepuasan pengunjung wisata di Swaziland menunjukkan adanya hubungan positif antara kepercayaan wisatawan terhadap daerah tujuan wisata. Kepercayaan dan kepuasan wisatawan terhadap daerah tujuan wisata menjadikan wisatawan itu sebagai pemberi rekomendasi untuk kelangsungan kegiatan wisata (Mashwama, V. C., Chiliya, N. and Chuchu, T. 2019). Kelangsungan kegiatan wisata dapat mendapat dukungan dari kegiatan organisasi kemasyarakatan dalam suatu kawasan. Kegiatan acara budaya, ritual, dan olahraga dapat menjadi penunjang peningkatan kualitas destinasi wisata. Oleh karena itu dukungan pemerintah untuk memberikan dukungan infra struktur dan manajemen menjadi faktor pendukung pengembangan dan kelangsungan suatu kawasan wisata (Jaruševičiene, 1. 2019).

Interaksi antara wisatawan dengan masyarakat domestik dalam kawasan tujuan wisata sangat relevan dalam kegiatan wisata di pedesaan. Interakasi antara pengunjung dengan masyarakat dapat dikelompokkan menjadi 3 bagian yaitu; mereka yang sedikit sekali berinteraksi, termasuk berinteraksi bagi sesama pengunjung, dan mereka yang intensif berinteraksi. Faktor interaksi antara masyarakat dengan wisatawan sebaiknya menjadi bagian dari aspek pemasaran wisata (Kastenholz, E., Carneiro, M. J. and Eusébio, C. 2018).

Kegiatan wisata yang mengunjungi desa untuk merasakan sensasi kehidupan desa telah berkembang di Taiwan dalam kurun waktu 10 tahun terakhir. Merasakan kuliner desa, menikmati buah segar, jalan jalan di lingkungan pedesaan, merasakan sensai bercocok tanam secara langsung adalah kegiatan desa yang menarik bagi wisatawan. Sikap, norma subjektif, dan persepsi mempengaruhi keinginan pelaku wisata di desa untuk merasakan sensasi bertani secara langsung (Feng-Yi Chang 2018).

Wisata desa di Indonesia masih menjadi barang langka yang belum disadari sepenuhnya oleh masyarakatnya. Beberapa daerah yang telah menyadari potensi ini dan berusaha mengembangkan potensinya untuk kemajuan desa. Pengembangan budaya lokal sebagai motor penggerak kegiatan wisata telah terbukti dalam proyek Querença. Proyek ini telah terbukti memberikan efek positif terhadap kawasan disekitarnya. Peluang yang sama akhirnya terbuka bagi desa lain yang ada disekitarnya (Cunha Lima, F. B. and Flores e Silva, Y. 2017).

Interaksi antara wisatawan dengan masyarakat di Indonesia terungkap sebagai hubungan timbal balik dalam hal kualitas nilai pengalaman. Nilai pengalaman ini sebagai nilai kemanusiaan yang meliputi berbagai aspek yang saling melengkapi. Wisatawan dan masyarakat setempat saling membutuhkan untuk pengembangan kepribadian mereka masing-masing (Bertella, G., Cavicchi, A. and Bentini, T. 2018)

Potensi budaya sebagai ujung tombak pengembangan wisata terungkap di Desa Budaya Gamcheon di Busan, Korea Selatan (Choi, Y. J. and McNeely, C. L. 2018). Desa yang tadinya miskin, berantakan, dan tidak teratur atau kumuh ditata dan dikembangkan menjadi desa dengan keindahan yang menarik wisatawan. Desa ini memiliki kebudayaan yang khas dan karya seni yang bernilai tinggi. Masyarakat, pengusaha dan seniman berkolaborasi berhasil mengubah citra desanya tertinggal menjadi cemerlang.

Fenomena pengembangan desa sebagai tujuan wisata tidak hanya terjadi di Negara luar. Indonesia dengan anugerah alam yang dimilikinya justru memiliki potensi yang lebih besar untuk mengembangkan kawasan desanya sebagai daerah tujuan wisata. Daerah yang telah dikaji 
untuk pengembangan wisata dengan fokus pedesaan adalah Dieng Kulon dan desa desa di Kabupaten Lombok Tengah. Karakter pengembangan wisata desa di Lombok tengah terungkap, pengelolaannya dipengaruhi oleh dua faktor signifikan yaitu persepsi masyarakat pesisir dan ekowisata pesisir. Faktor ini mempengaruhi pengembangan desa wisata mandiri dan desa wisata pantai. Mustajab Hakim et al. (2018). Pengembangan potensi desa sebagai kawasan wisata di Indonesia juga dikaji di desa Dieng Kulon. Desa ini juga terbukti memiliki potensi untuk dikembangkan menjadi desa wisata (Setiawan, B. and Wiweka, K. 2018).

Kelangsungan kegiatan wisata tidak dapat dipisahkan dengan kebutuhan akan energi. Masalah ini sering menjadi kendala yang dihadapi dalam pengembangan wisata desa akibat jaraknya yang jauh dari sumber. Energi telah menjadi kebutuhan utama dalam kelangsungan hidup dalam dunia modern ini. Ketersediaan sumber energi mampu memberikan nilai tersendiri bagi suatu kawasan termasuk kawasan wisata. Permasalahan yang umum terjadi adalah keterbatasan layanan sumber energi khususnya di daerah terpencil atau daerah pedesaan. Kalaupun energi tersedia kadang kurang terjangkau oleh masyarakatnya. Desa sebagai sumber potensi wisata yang menjajikan keuntungan ekonomi untuk pengembagan kawasan memerlukan pemikiran pengadaan sumber energi terutama listerik. Kajian pengembangan penggunaan sumber energi di desa wisata dengan target nol energy untuk kebutuhannya dilakukan oleh Fahd Diab, Hai Lan, Lijun Zhang \& Salwa Ali 2015. Desa Alexandria di Mesir adalah lokasi kajiannya yang mengungkapkan bahwa mengoptimalkan energi terbarukan dan meminimalkan emisi gas rumah kaca dengan cara menggabungkan energy surya, angin dan diesel.

Potensi pengembangan desa sebagai daerah tujuan wisata di Indonesia yang umum adalah keindahan alamnya. Alam pesisir dan alam pegunungan merupakan modal besar bagi desa-desa di Indonesia. Desa dengan potensi keindahan alam pesisir yang mendapatkan nilai tambah potensi budaya dan relegi merupakan model yang cukup besar untuk dikembangkan menjadi desa wisata.

Potensi desa Cikoang menjadi tujuan wisata yang menjanjikan kesuksesan didukung oleh berbagai faktor diantaranya: 1. Faktor lingkungan yang berada di muara sungai sebagai magnet pesisir. 2. Desa ini menyandang nilai historis. 3. Budaya maritim dan budaya relegi.

Berdasarkan kajian penelitian yang telah terungkap bahwa kegiatan wisata desa berpotensi sebagai motor penggerak pengembangan suatu kawasan. Pengembangan desa wisata memerlukan peran masyarakat sebagai penyebar informasi dan upaya pelestarian kegiatan wisata termasuk interaksi masyarakat dengan wisatawan. Peran masyarakat berinteraksi dengan wisatawan dapat menjadi bagian yang dapat melanggengkan kegiatan wisata desa. Peran pemerintah dalam hal pengembangan wisata dibutuhkan dalam hal penyiapan infra struktur. Kegiatan wisata desa yang mulai berkembang adalah kegiatan wisata partisipasi yang memungkinkan wisatawan merasakan langsung aktifitas kegiatan masyarakat desa. Hasil penelitian tersebut yang terungkap bahwa tinjauan wisata desa dikaitkan dengan kondisi potensi desa yang dimiliki Cikoang menunjukkan kelayakan yang sangat optimistik dan menghampiri sempurna. Desa dengan potensi relegi, budaya, yang berada dalam suasana pesisir muara hampir tidak memiliki celah negatip untuk menafikan keunggulannya sebagai desa wisata. Semua potensi yang diidamkan oleh penikmat wisata terangkum menjadi satu di Desa Cikoang.

Dengan demikian rancangan konfigurasi ruang permukiman Cikoang berbasis Desa wisata yang merupakan perwujudan aspek relegi, budaya, dan potensi alam tepian air secara 
terpadu adalah solusi yang tepat untuk dipersembahkan kepada masyarakat di kawasan ini.

\section{Metode}

Metode pelaksanaan penelitian pengabdian ini dilakukan menurut tahapan pendekatan ilmiah. Secara garis besar diawali dengan pengenalan lokasi, pendalaman permasalahan, dilanjutkan dengan survey mendalam, hasil survey mendalam kemudian dianalisis sesuai pandangan tatanan arsitektural. Tahap selanjutnya adalah pengembangan gagasan penyelesaian permasalahan. Hasil pendalaman masalah di lokasi perencanaan ditemukan adanya potensi yang belum dimanfaatkan secara optimal. Penjajakan pengenalan lanjutan di lokasi menemukan adanya potensi dan kendala yang perlu dikembangkan dan perlu efek negatip yang perlu diminimalisir. Potensi yang perlu dikembangkan adalah keindahan alam panorama muara sungai yang didukung oleh potensi keramahan masyarakat, pemanfaatan tambak garam sebagai media pendidikan bagi generasi muda. Unsur yang perlu diminmalisir yaitu; penataan tepi sungai yang telah mengalami erosi pembatasan pengembangan permukiman oleh masyarakat yang mengarah ke sungai sebagaimana layaknya reklamasi. Hasil pengenalan lokasi kemudian dianalisis. Hasil analisis selanjutnya disosialisasikan dengan pemerintah setempat dan dengan masyarakat.

Alat yang digunakan dalam untuk menyampaikan ide pengembangan kawasan adalah perangkat lunak komputer yang merupakan gabungan berbagai computer grafis yang disesuaikan dengan peruntukannya. Perekaman suasana lingkungan menggunakan kamera hand phone. Eksekusi rancangan mengguanakan software Auto Cad, Revit 2016, Corel Draw 19, dan untuk rendering image menggunakan revit dan lumion 7.

\section{Hasil dan Diskusi}

Kawasan desa yang penuh potensi ini rupanya belum ditangani secara serius sebagaimana layaknya. Potensi yang ada bagaikan mutiara yang masih tertimbun. Sarana dan prasarana lingkungan tampak dibuat seadanya tidak terencana dengan baik sehingga lingkungan visual tidak berimbang dengan kondisi keindahan alamiahnya.

Maudu lompoa adalah kegiatan yang khusus terselenggara ditempat ini sebagai kegiatan gabungan antara religi dan budaya. Kegiatan ini telah dilengkapi dengan bangunan baruga dan tempat acara prosesi doa maudu lompoa. Bangunan yang terbuat dari kayu dan rancangan yang ada dirasakan tidak memadai oleh masyarakat setempat. Kurangnya pertimbangan terhadap kesesuaian antara aktifitas dengan hasil rancangan dan penempatan bangunan membuatnya tidak mendukung kegiatan. Keterbatasan utama yang dirasakan adalah sempitnya lokasi. Hal ini disampaikan oleh penduduk yang sedang berada dilokasi pada saat kunjungan pendahuluan. 

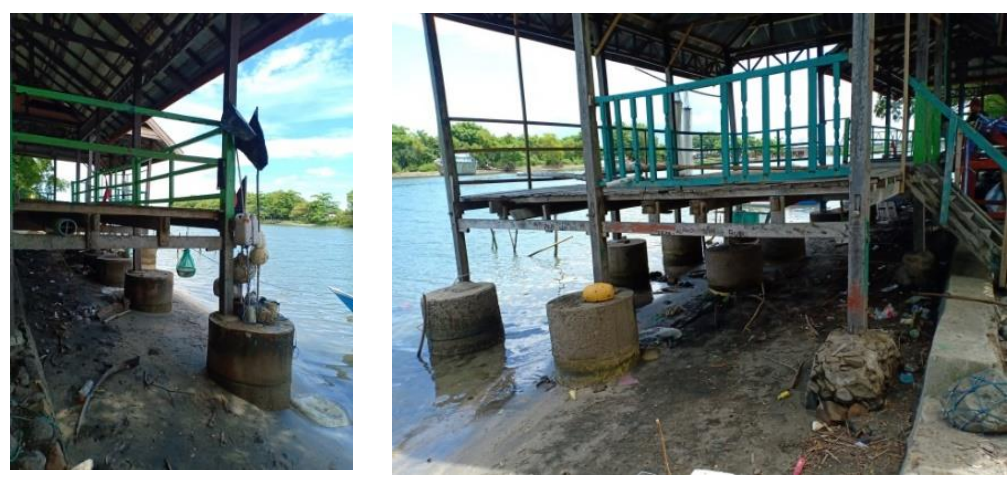

Gambar 2. Fasilitas upacara ritual maudu lompoa

Gambar 2 adalah fasilitas addateq (ritual khusus) Fasilitas ini adalah tempat pembacaan barazanji dan kegiatan keagamaan lainnya yang berhubungan dengan prosesi acara maudu lompoa (maulid besar).
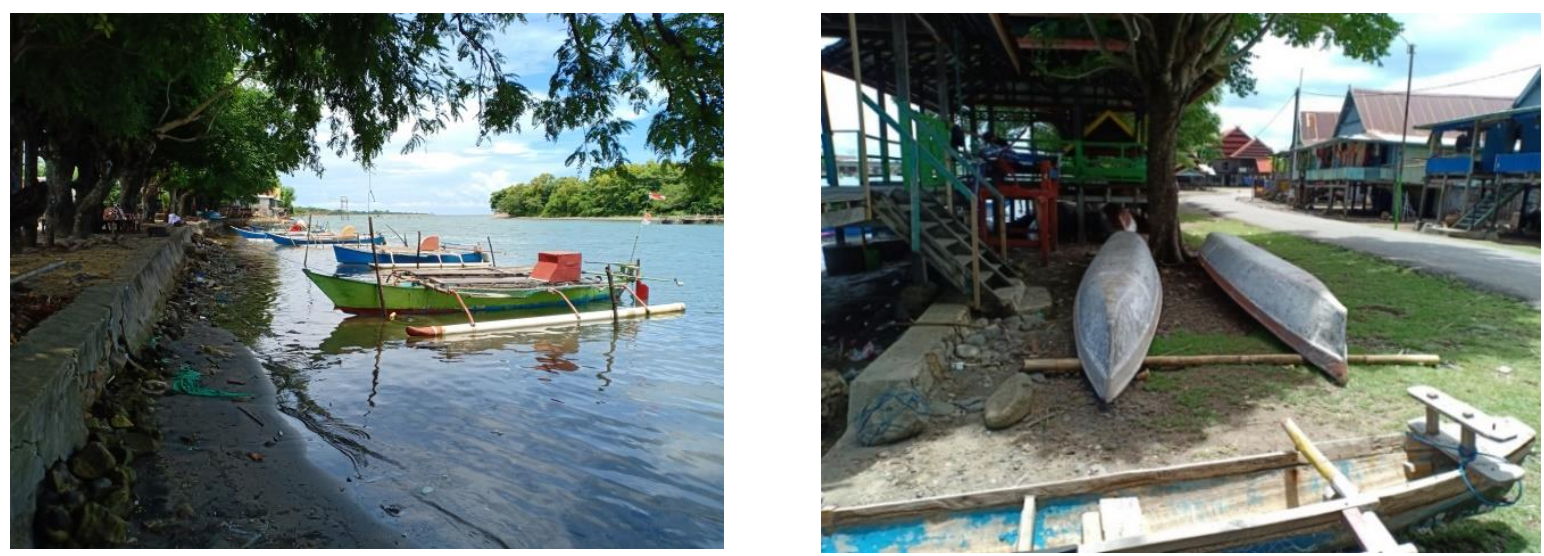

Gambar 3. Perahu tertambat di tepi sungai berlatar belakang muara Cikoang

Lokasi tempat perahu ini adalah lokasi yang digunakan untuk menambatkan perahu yang ikut prosesi acara maudu lompoa dan pada hari biasa digunakan sebagai tempat parkir perahu bagi masyarakat. Penataan parkir perahu untuk menunjang aktifitas nelayan dan prosesi ritual perlu mendapatkan sentuhan teknis perencanaan secara terpadu.

Gambar 3 kanan menunjukkan adanya 2 (dua) unit perahu berwarna putih yang ditelungkupkan oleh masyarakat. Perahu ini sesungguhnya adalah ambulance air yang digunakan untuk mengantar janazah ke tempat pekuburan yang ada di tepi sungai yang disebut jeraq letteq. Prosesi pengantaran janazah melalui air adalah satu keunikan aktifitas masyarakat Cikoang. Permasalahan yang disampaikan oleh masyarakat dalam wawancara singkat adalah kesulitan ketika memuat janazah dan saat memarkir ambulance tersebut. Menurut informasi kepala desa jumlah ambulance ini akan ditambah. 


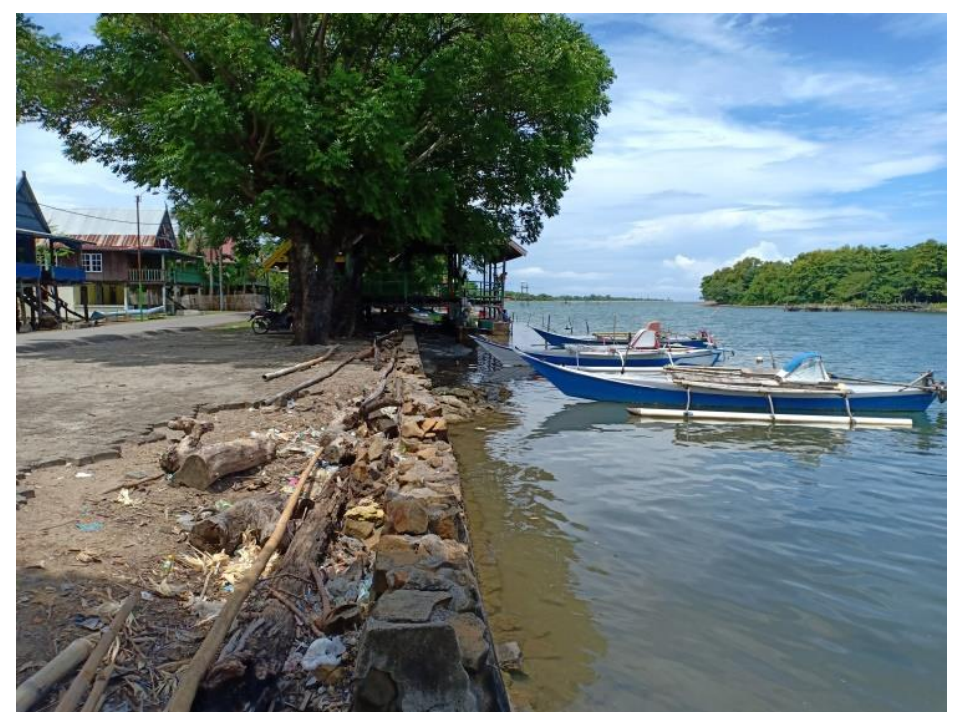

Gambar 4. Fasiltas tanggul penahan tanah ditepi sungai Cikoang yang hancur

Kawasan tepi air menghadapi masalah teknis yang perlu diselesaikan secara tepat. Pertemuan antar air dan darat mengundang permasalahan berupa kikisan tanah oleh aliran air yang berlangsung secara kontinu. Gambar 4 memperlihatkan konstruksi penahan tanah telah mengalami kerusakan. Gejala teknis umum adalah pasangan batu terlepas dari ikatannya dan patah di beberapa tempat. Kondisi seperti ini ditemukan sebagai gejala umum di tempat ini.

\subsection{Potensi Lokasi}

Potensi lokasi perencanaan dapat dijelaskan melalui gambar 5 di bawah. Lokasi terletak di muara sungai Cikoang yang diapit oleh sungai besar dan anak sungai. Sisi timur diisi dengan tambak pembuatan garam.
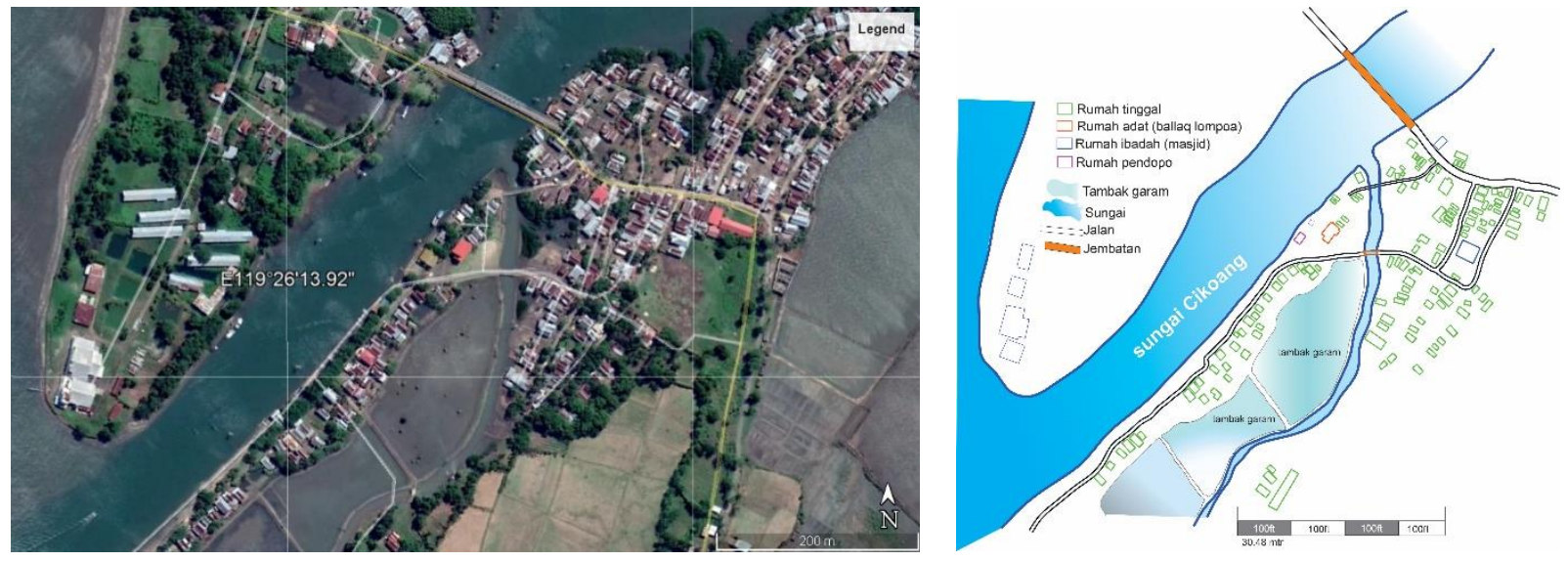

Gambar 5. Eskisting lokasi kawasan perencanaan 


\subsection{Permasalahan Kawasan}

Pengamatan pintas dari kondisi tersebut dapat dijelaskan bahwa terlepasnya batu dari ikatan pemasangannya adalah akibat hempasan air yang terjadi secara kontinu. Sementara patahnya dinding penahan tanah terjadi akibat panjang pasangan yang tidak dilengkapi dengan deletasi. Alternatif penyebab lainnya adalah kondisi daya dukung tanah di daerah tepi air dalam rentang jarak yang panjang tidak dapat dijamin kesamaan kemampuannya. Bilamana pasangan batu yang duduk di atas tanah menempati daerah yang lembek akan menyebabkan terjadinya penurunan secara berangsur yang pada akhirnya akan menjadi patah.

Berdasarkan uraian di atas permasahan mitra dapat dikemukakan sebagai berikut:

1) Penataan kawasan tepi air Cikoang perlu dibuatkan pedoman pelaksanaan pembangunan secara terpadu dan teritegrasi.

2) Penataan kawasan berpotensi sebagai kawasan desa wisata dengan mengoptimalkan potensi alami yang dimilikinya.

3) Penyediaan perencanaan sarana dan prasarana lingkungan yang mendukung prosesi ritual dan budaya perlu dijadikan sebagai dasar pertimbangan rancangan kawasan.

4) Penataan lingkungan tepi air berpotensi dikembangkan sebagai sarana rekreasi desa bahari.

5) Sarana dan prasarana penunjang perahu perlu di desain khusus agar kebutuhan dasar fasilitas menjadi elemen estetika lingkungan.

Kunci permasalahan dari uraian diatas adalah bagaimana bentuk rancangan konfigurasi ruang permukiman Cikoang berbasis Desa wisata yang merupakan perwujudan aspek relegi, budaya, dan potensi alam tepian air secara terpadu.

\subsection{Usulan peningkatan kualitas lingkungan}

Berdasarkan permasalahan kawasan perencanaan diusulkan, penyelesaian teknis arsitektural yang meliputi rencana tata ruang lingkungan dan penataan kawasan tepi sungai. Penataan tata ruang lingkungan permukiman diusulkan dengan mengikuti gagasan berikut.

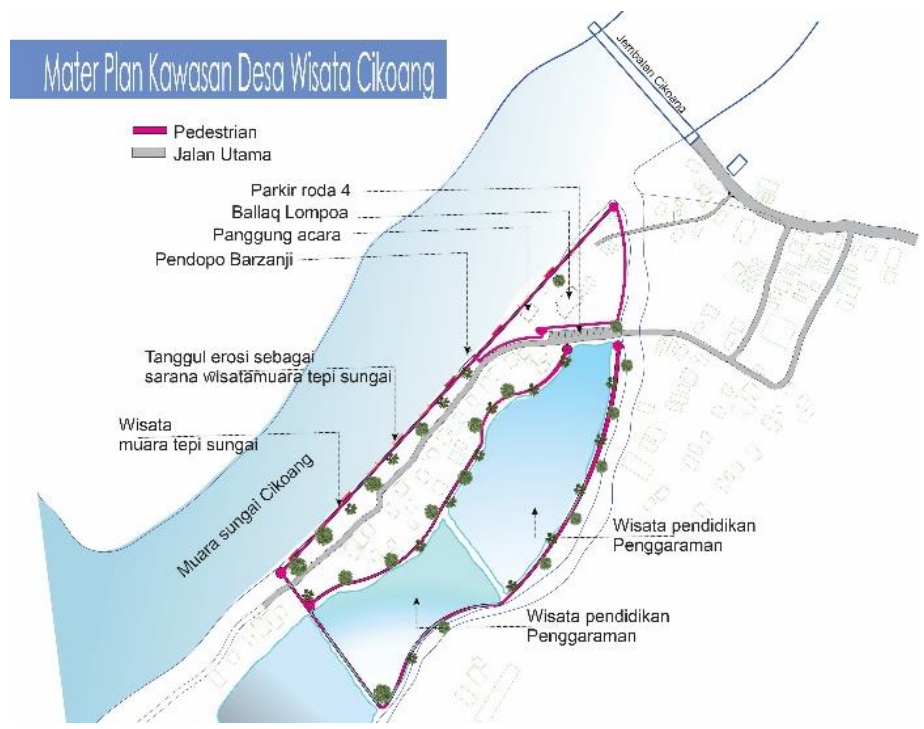

Gambar 6. Usulan rencana tata ruang Kawasan perencanaan 
Kawasan tepi air disarankan dipasang tanggul penahan erosi yang juga berfungsi sebagai sarana rekreasi muara tepi sungai. Batas air dan darat dibuat ring belt berupa pedestrian yang berfungsi sebagai jalur rekreasi aktif disepanjang kawasan dan berfungsi sebagai sempadan batas air. Penghijauan antar fungsi perlu diperhatikan untuk meningkatkan kualitas lingkungan.

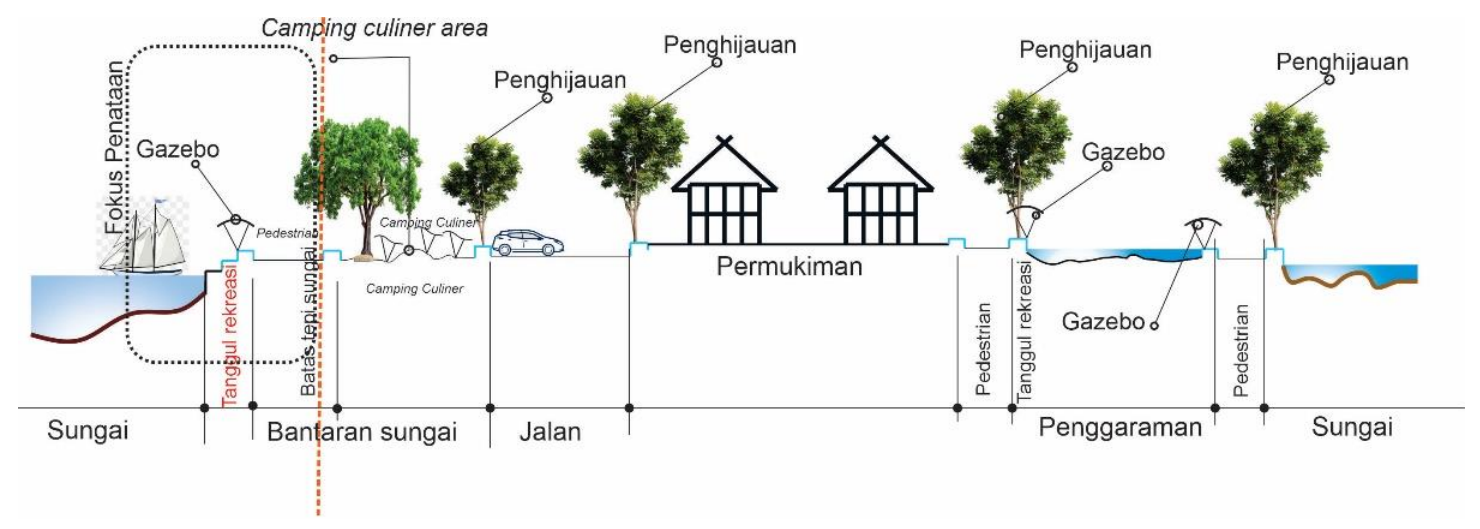

Gambar 7. Potongan lingkungan rencana

Potongan lingkungan usulan pengembangan kawasan sebagaimana dalam gambar di atas memperlihatkan urutan fungsi menurut potongan dari kiri ke kanan. Dimulai dengan pemasangan turap penahan erosi yang ditempel dengan pedestrian. Sisa lahan yang terbentuk dari timbunan hingga batas jalan sebaiknya dibuat kontur yang meyerupai bukit kecil di bantaran sungai, ruang ini digunakan sebagai area camping culiner atau kawasan kuliner tidak tetap. Jalan eksisting tidak diganggu kecuali penambahan penghijauan dikedua sisinya. Area kawasan permukiman juga tidak diganggu kecuali penambahan penanaman pohon. Bagian batas antar permukiman dengan tambak diberikan penghijauan dan dibatasi dengan pedestrian dikedua sisinya. Tambak ini digunakan sebagai area pendidikan untuk proses pembuatan garam. Selanjuntnya anak sungai yang ada di bagian kanan juga diberikan pasangan pedestrian dan penghijauan ditepi sungai kecil.

Konstruksi penahan erosi di kawasan tepi sungai yang digunakan sebagaimana diperlihatkan dalam gambar di bawah telah mengalami kerusakan di beberapa titik. Kerusakan ini nampaknya terjadi akibat daya dukung tanah yang tidak sama dalam rentang bentang yang panjang. Konstruksi yang terpasang terdiri dari pasangan batu kali dengan pengikat specie dalam rentang bentang yang panjang tanpa adanya deletasi. Metode konstruksi seperti ini membuka peluang terjadinya patahan dalam rentang bentang yang panjang dan kualitas pelaksanaan yang tidak seragam. Kondisi seperti ini mengakibatkan terjadinya retakan dan terlepasnya batu dari pasangannya. 

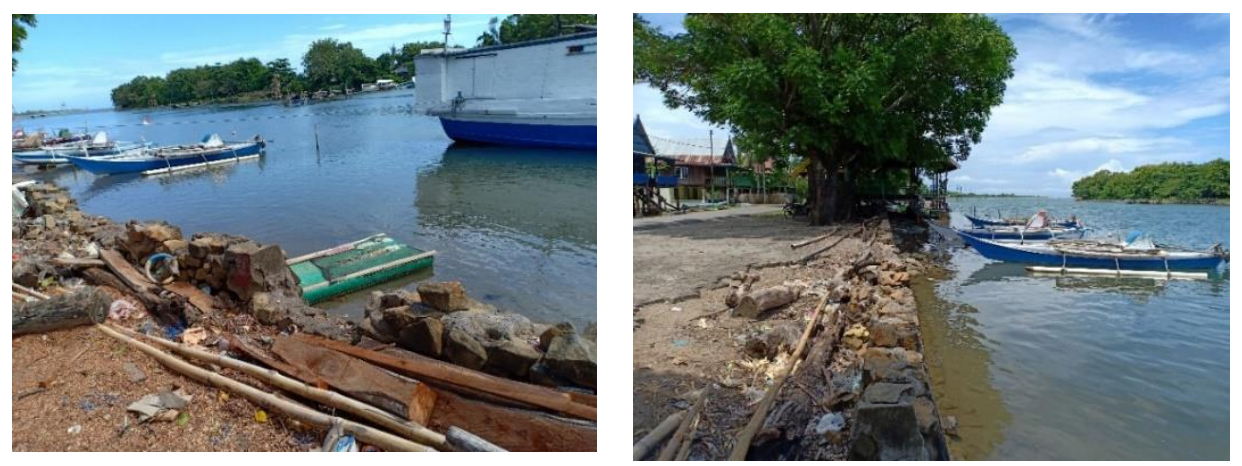

Gambar 8. Konstruksi penahan tanah yang cenderung terlepas dari ikatan pasangan specie

Konstruksi usulan penahan erosi yang digabungkan dengan fungsi sarana rekreasi diusulkan menggunakan metode konstruksi sebegaimana dalam gambar di bawah.
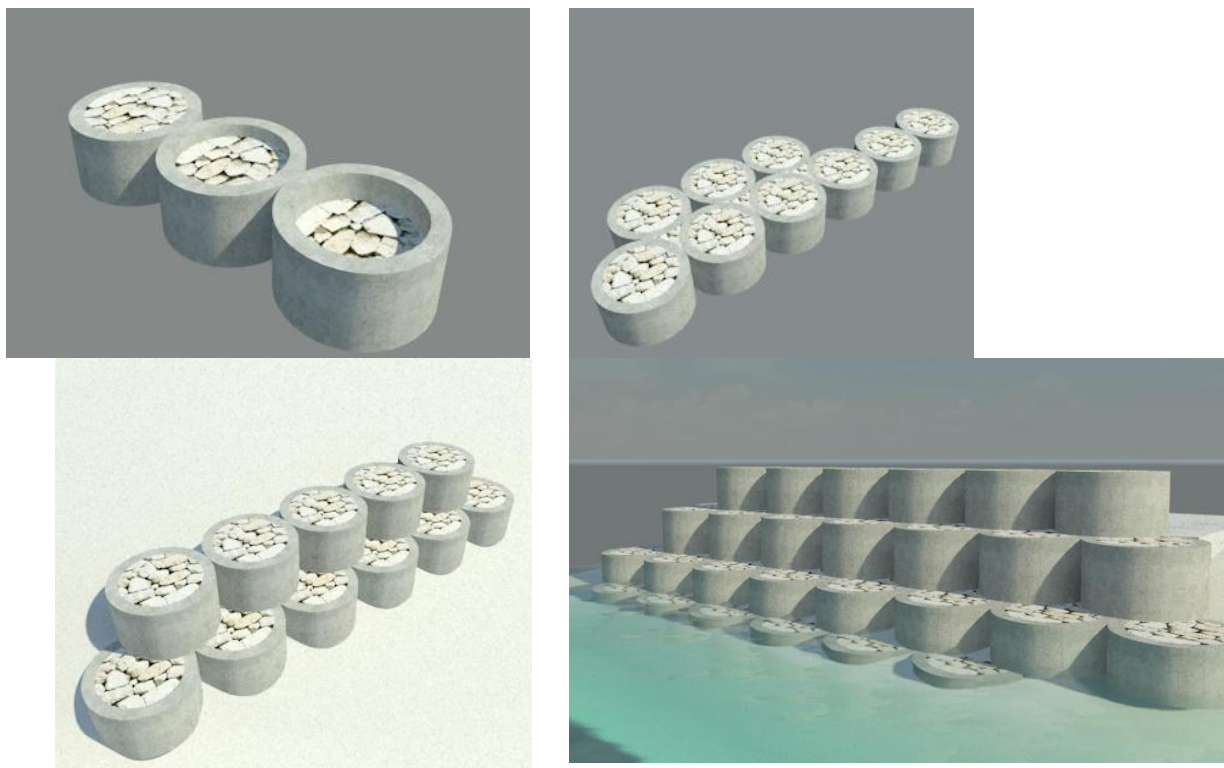

Gambar 9. Konstruksi penahan tanah tepi sungai

Buis beton diameter $80 \mathrm{~cm}$ dipasang sejajar berbentuk garis sesuai dengan rancangan yang ada. Buis ini kemudian diisi dengan batu kali sebagai pemberat tanpa specie. Tinggi susunan lapisan buis disesuaikan dengan tinggi permukaan yang dikehendaki. Keuntungan yang diperoleh dengan menggunakan metode ini adalah konstruksi diberi kemungkinan pergeseran akibat perubahan kondisi tanah dasar dan atau desakan beban air yang sifatnya dinamis. Konstruksi ini memungkinkan terjadinya pergerakan yang menyesuaikan dengan kondisi medan dan pengaruh luar. Keuntungan lain yang diperoleh adalah kemudahan dalam perbaikan. 

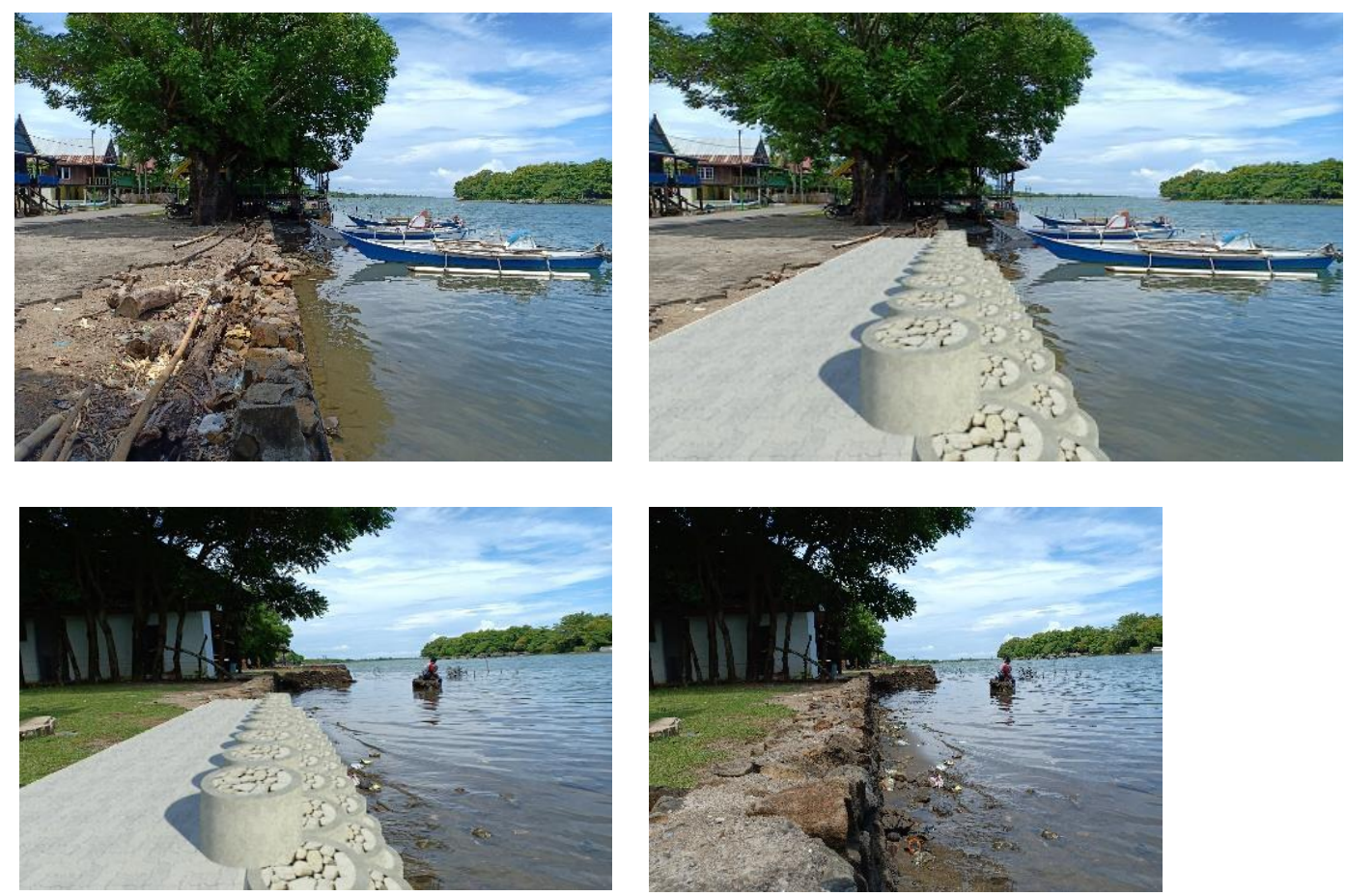

Gambar 10. Ilustrasi peningkatan kualitas tanggul erosi

Ilustrasi penyelasaian tepi sungai menggunakan turap buis beton yang berfungsi ganda sebagai tempat wisata air diperlihatkan dalam gambar 10.

Keuntungan komposisi buis sebagaimana disarankan dapat memberikan keuntungan dalam hal penggunaanya sebagai tempat duduk menikmati keindahan panorama sungai dan akan berfungsi sebagai tempat penyimpanan sementara keranjang atau wadah hasil melaut. Perahu yang sandar dengan mudah dapat menyesuaikan dengan kondisi ketinggian permukaan air.

Fasilitas penunjang kegiatan yang tidak tersedia adalah tambatan tali perahu. Untuk memenuhi kebutuhan ini akan digunakan tiang yang terbuat dari pipa PVC diameter 4 inchi yang diisi dengan campuran beton. Penggunaan bahan PVC dianggap lebih tepat karena bahan ini lebih tahan terhadap kemungkinan korosi dari pengaruh air garam. Pipa PVC ini juga akan berfungsi sebagai bekesting pembentuk tiang.

Gambaran suasana lingkungan tepi air muara Cikoang menurut usulan rancangan disajikan tampilan gambar berikut:
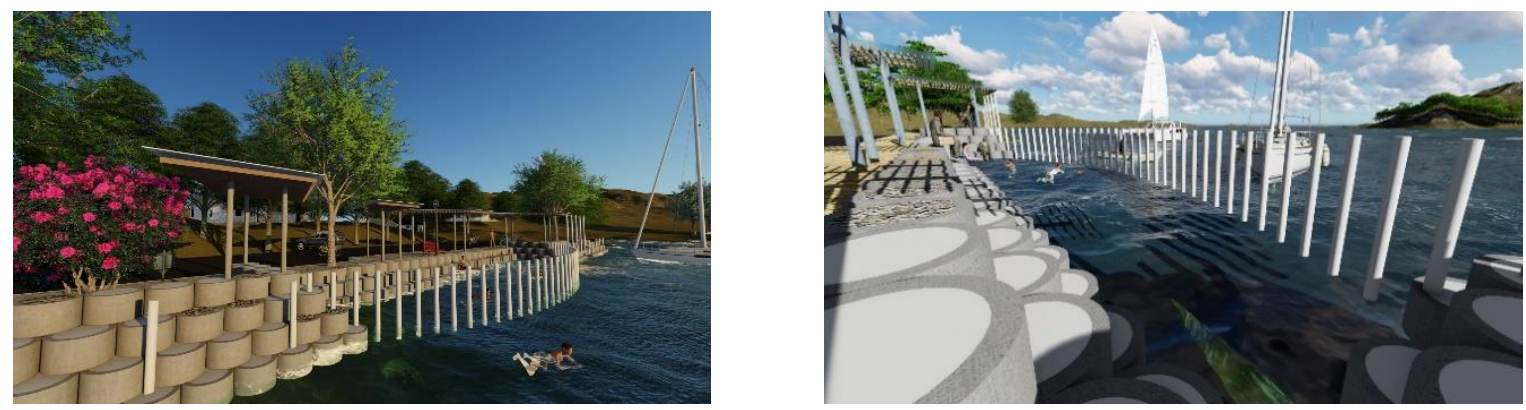

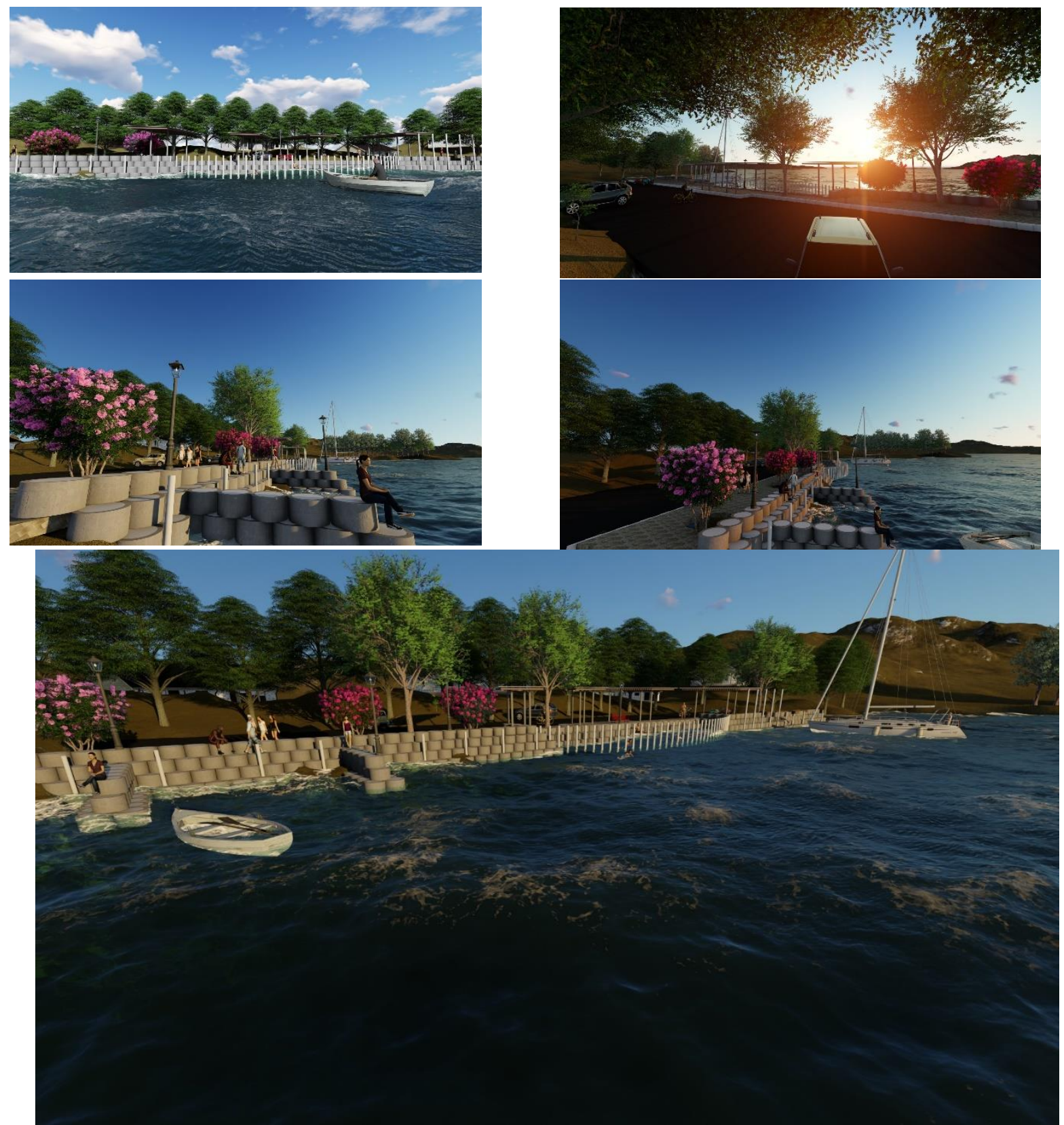

Gambar 11. Ilustrasi suasana lingkungan usulan rencana penataan kawasan Cikoang sebagai desa wisata

\subsection{Sosialisi Hasil Kajian}

Hasil kajian kemudian disosialisasikan kepada masyarakat untuk mengukur tanggapan masyarakat atas usulan rancangan yang telah dikembangkan. Kegiatan ini juga sebagai sarana menjaring ide atas kebutuhan yang lebih urgen. Sosialisai karya dilakukan dengan mengikuti prosedur kesehatan untuk menghindari penyebaran covid-19. Metode sosialisasi diselenggarakan menggunakan media poster dan buku executive summary. Masyarakat yang dilibatkan dalam jumlah tertentu maksimal 5 orang berjarak dan bermasker. Gambar berikut memperlihatkan gambaran suasana ketika sosialisasi dilakukan. 

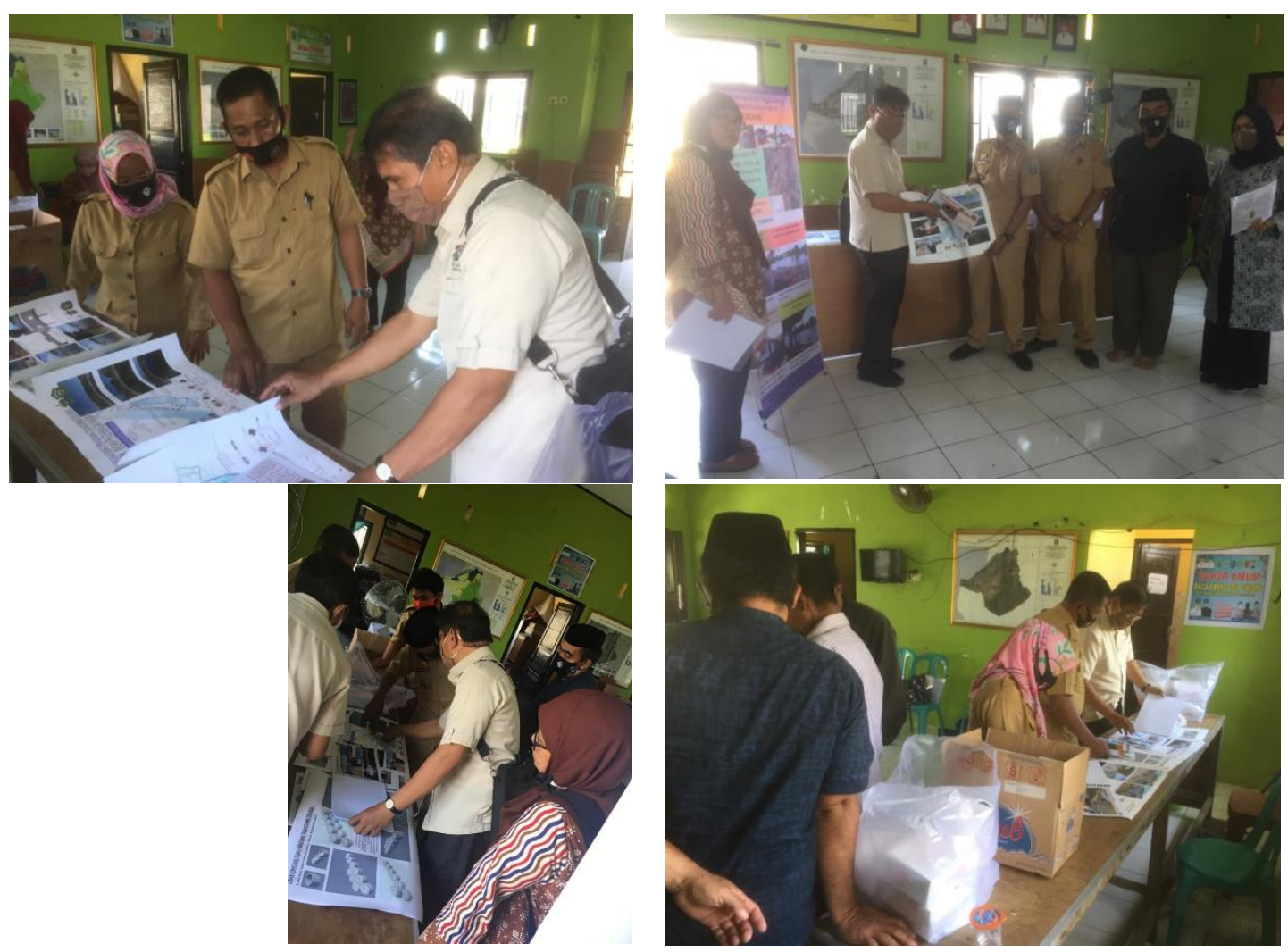

Gambar 12. Sambutan masyarakat dan Pemerintah Desa

Sambutan masyarakat dan Pemerintah Desa sangat baik atas gagasan yang disajikan untuk penataan desanya sebagai rencana kawasan wisata. Keterangan yang disampaikan sebagai penghargaan atas hasil gagasan rencana yang disajikan adalah penggunaan materi ini sebagai bahan dalam pembahasan penggunaan anggaran dana desa.

Rancangan yang disajikan sesungguhnya adalah hal yang sejalan dengan keinginan masyarakat. Kendala yang mereka hadapi adalah kurangnya kemampuan visualisai ide dan pengembangannya. Konstruksi penahan erosi yang diusulkan pada dasarnya telah dilakukan oleh mayarakat secara swadaya. Kegiatan masyarakat tersebut dirasakan menjadi kurang setelah melihat perbandingan dengan gagasan yang disajikan oleh tim. Kekurangan yang mereka sadari meliputi komposisi dan pengembangan lahan yang lebih optimal. Komposisi buis penahan erosi dilakukan secara sederhana, tidak dibuat berbentuk berundak tangga untuk mendukung aktifitas nelayan. Penempatan posisi buis penahan erosi diletakkan ditepi sungai eksisting. Saran yang dikembangkan adalah dengan menarik turap kedalam sungai untuk mengembalikan tepi sungai eksisting. Pengembalian bantaran sungai eksisting memberikan nilai tambah berupa lahan yang lebih luas ditepi sungai. Lahan yang baru dikembalikan tersebut dimanfaatkan sebagai jalur pedestrian yang sekali gus berfungsi sebagai sempadan sungai.

\section{Kesimpulan}

Kawasan pesisir muara Cikoang Desa Cikoang Kecamatan Mangarabombang Kabupaten Takalar memiliki potensi yang sangat besar untuk dikembangkan menjadi kawasan wisata desa. Kawasan ini memiliki keindahan alam yang sangat cantik dari muara sungai. Keindahan alam ini didukung 
oleh potensi penduduk yang berprofesi sebagai nelayan dengan hasil tangkapan ikan segar sepanjang waktu.

Secara umum desa Cikoang memiliki potensi yang dapat dikembangkan untuk menjadi desa wisata. Dukungan ini meliputi potensi kegiatan wisata pendidikan, wisata alam, dan wisata budaya. Potensi ini perlu didukung oleh semua pihak secara terintegrasi menurut perannya masing-masing. Pemerintah perlu mendukung dalam hal penyiapan infra struktur. Masyarakat perlu berperan dalam hal pelestarian dan penyebaran informasi serta keramahan komunikasi. Jaminan keramahan ini berfungsi sebagai pelanggeng kelangsungan dan perekat kesan bagi wisatawan. Layanan dan berinteraksi dengan wisatawan diperlukan sebagai pengikat dan pemberi kesan bagi pengunjung. Kepuasan pengunjung dapat memberi kepuasan wisatawan yang berkunjung.

Potensi kawasan ini sebagai desa wisata perlu didukung peningkatan kualitas lingkungan. Adapun tahapan pembangunan yang dibutuhkan meliputi tiga tahap menurut kepentingannya. Tahapan pembangunan yang paling mendesak adalah pembangunan talud penahan erosi sungai yang sekaligus berfungsi sebagai sarana penunjang wisata pesisir muara sungai. Tuntutan kedua adalah pembangunan akses pedestrian sepanjang pesisir muara yang digunakan sebagai batas sempadan sungai dan sebagai jalur sirkulasi distribusi produk nelayan. Tahapan tingkat tiga adalah pembangunan sarana penunjang kegiatan wisata muara sungai berupa camping culiner. Sarana ini meliputi pengadaan lapangan terbuka untuk kegiatan kuliner ikan segar yang direncanakan secara periodik menurut musim tangkapan ikan jenis tertentu.

Fasilitas penunjang peningkatan kualitas rekreasi muara sungai yang dapat ditambahkan dalam kegiatan ini adalah belajar renang di sungai dengan aman dan nyaman. Kegiatan ini diperuntukkan bagi pemula yang ingin belajar renang termasuk anak-anak. Fasilitas ini tersedia secara langsung berpasangan dan menjadi satu kesatuan dengan penataan turap penahan erosi. Jaminan keamanan dan kenyamanan difasilitasi oleh pemasangan tiang-tiang pembatas yang terbuat dari pipa pvc diamaeter 4 inchi yang diisi dengan bahan beton. Fungsi lain dari pemasangan pipa tersebut adalah sebagai batang tempat tambatan perahu nelayan.

Pembangunan sarana dan prasarana penunjang sebagaimana disebutkan akan meningkatkan aura positif desa Cikoang sebagai desa wisata yang dapat meningkatkan perekonomian masyarakat.

\section{Ucapan Terima Kasih}

Penghargaan atas pelaksnaan kegiatan ini disampaikan kepada segenap jajaran pimpinan Fakultas Teknik Universitas Hasanuddin atas dukungan finansial dan kebijakan untuk alokasi kegiatan Pengabdian Masyarakat.

Ucapan Terima Kasih disampaikan kepada segenap jajaran pimpinan Pemerintah Daerah Tingkat II Takalar dalam hal ini mulai dari Bapak Kepala Desa Cikoang, Bapak Camat Kecamatan Mangarabombang dan Bapak Bupati Kepala Daerah atas dukungan kerja sama dan kesempatan yang diberikan kepada kami. Ucapan yang sama tak lupa disampaikan kepada segenap masyarakat Cikoang yang telah memberikan informasi dan suguhan keramatamahan saat kami berada di lokasi. Hanya Allah Yang Maha Kuasa yang patut memberi imbalan atas jasa dan sumbangsi bapak ibu. Semoga aktifitas ini dapat bernilai ibadah. 


\section{Daftar Pustaka}

Bertella, G., Cavicchi, A. and Bentini, T. (2018) 'The reciprocal aspect of the experience value: tourists and residents celebrating weddings in the rural village of Petritoli (Italy)', Anatolia: An International Journal of Tourism \& Hospitality Research, 29(1), pp. 52-62. doi: 10.1080/13032917.2017.1381854.

Choi, Y. J. and McNeely, C. L. (2018) 'A Reinvented Community: The Case of Gamcheon Culture Village', Sociological Spectrum, 38(2), pp. 86-102. doi: 10.1080/02732173.2018.1430635.

Cunha Lima, F. B. and Flores e Silva, Y. (2017) "Project Querença” and creative tourism: visibility and local development of a village in the rural Algarve', E-review of Tourism Research, 14(1/2), pp. 21-35. Available at: http://eresources.perpusnas.go.id:2077/login.aspx ?direct=true $\& d b=h j h \& A N=126988239 \&$ site $=e d s-$ live (Accessed: 20 March 2020).

Fahd Diab et al. (2015) 'An Environmentally-Friendly Tourist Village in Egypt Based on a Hybrid Renewable Energy System-Part Two: A Net Zero Energy Tourist Village', Energies, (7), p. 6945. doi: 10.3390/en8076945.

Feng-Yi Chang (2018) 'Factors That Influence Tourists to Join Agriculture Activities', International Journal of Organizational Innovation, 11(1), pp. 1-10. Available at: http://eresources.perpusnas.go.id:2077/login.aspx?direct=true \&db=ent\&AN=130867054\&site=edslive (Accessed: 20 March 2020).

JARUŠEVIČIENE, L. (2019) 'Development of Cultural and Sporting Activities in Villages', Humanities Bulletin of Zaporizhzhe State Engineering Academy, (77), pp. 123-132. doi: 10.30839/2072-7941.2019.177740.

Kastenholz, E., Carneiro, M. J. and Eusébio, C. (2018) 'Diverse socializing patterns in rural tourist experiences - a segmentation analysis', Current Issues in Tourism, 21(4), pp. 401421. doi: 10.1080/13683500.2015.1087477.

MATEI, D. (2018) 'Conflicts in tourism and sustainable development in Moieciu de Sus Village, Moieciu Resort, Romania', JETA: Journal of Environmental \& Tourism Analyses, 6(1), pp. 32-42. doi: 10.5719/jeta/6.1/3.

Mashwama, V. C., Chiliya, N. and Chuchu, T. (2019) 'Destination Image of Swaziland: Perceptions of Local and International Tourists', E-review of Tourism Research, 16(4), pp. 271-293. Available at: http://eresources.perpusnas.go.id:2077/login.aspx ?direct=true $\& d b=$ hjh $\& A N=136817852 \&$ site $=$ edslive (Accessed: 20 March 2020).

Mustajab Hakim et al. (2018) 'Coastal Tourism Management Model toward Developing Independent Tourist Village in Central Lombok District, Indonesia', Resources, (4), p. 69. doi: 10.3390/resources7040069.

Olcer, C. and Ekiz, E. H. (2016) 'Community Perception of Sustainable Tourism Development for a Newly Developing Destination: The Case of Baksı', Journal of Tourism \& Services, 7(13), pp. 35-43. Available http://eresources.perpusnas.go.id:2077/login.aspx ?direct=true $\& d b=h j h \& A N=120480688 \&$ site $=$ edslive (Accessed: 20 March 2020).

PEI-HSIN HSU (2018) 'Tourist Perceptions of Living Authenticity in Indigenous Tourism Destinations: The Case of Smangus Village in Taiwan', Tourism Culture \& Communication, 18(2), pp. 117-131. doi: 10.3727/109830418X15230353469500. 
Setiawan, B. and Wiweka, K. (2018) 'A Study of the Tourism Area Life Cycle in Dieng Kulon Village', Pertanika Journal of Social Sciences \& Humanities, 26T, pp. 271-278. Available at:http://e-

resources.perpusnas.go.id:2077/login.aspx?direct=true $\& \mathrm{db}=\mathrm{hlh} \& \mathrm{AN}=134081708 \&$ site $=$ edslive (Accessed: 20 March 2020). 